\title{
Nursing workload in a coronary unit according to the Nursing Activities Score
}

\author{
Carga de trabalho em unidade coronariana segundo o Nursing Activities Score \\ Carga de trabajo en unidad coronaria según la Nursing Activities Score
}

\author{
Rejane Reich ${ }^{a}$ \\ Débora Feijó Villas Bôas Vieirab \\ Luciana Bjorklund de Limac \\ Eneida Rejane Rabelo-Silva ${ }^{d}$
}

\begin{abstract}
Objective: this study aimed to using the Nursing Activities Score to assess nursing workload in a coronary care unit, to assess the distribution of workload between shifts, and to compare the current staff of the care unit with that recommended by the instrument. Method: this was a longitudinal study, conducted in a teaching hospital in Southern Brazil, between April to June 2012.

Results: A total of 604 NAS measures were obtained from the 61 patients included. The mean workload per shift was $47 \%$ ( \pm 12 ), with the greatest workload being reported in the afternoon shifts.

Conclusion: according to the NAS, a mean of two and a maximum of 2.4 nursing professionals would be required per shift to meet all patient demands, suggesting that the current staff size in the CCU is adequate. The NAS was successful in assessing nursing workload and changes in patient demands over time.
\end{abstract}

Keywords: Nursing. Cardiology. Intensive care. Workload.

\section{RESUMO}

Objetivo: verificar a carga de trabalho de enfermagem aferida pelo Nursing Activities Score em uma unidade coronariana, analisar sua relação com os turnos de trabalho e comparar o quadro de enfermagem existente na unidade com o projetado segundo os dados do instrumento.

Método: estudo longitudinal conduzido em um hospital universitário da região sul do Brasil no período de abril a junho de 2012. Foram realizadas 604 medidas por turnos, em uma amostra de 61 pacientes. A carga de trabalho foi de 47\% ( \pm 12 ) na análise por turnos, com média mais elevada no turno da tarde.

Resultados: observou-se a necessidade de em média dois e até 2,4 profissionais de enfermagem, estando condizente com o quantitativo real da unidade.

Conclusão: 0 instrumento possibilitou mensurar a carga de trabalho de enfermagem e delinear a variabilidade das demandas nos diferentes turnos de trabalho.

Palavras-chave: Enfermagem. Cardiologia. Terapia intensiva. Carga de trabalho.

\section{RESUMEN}

Objetivo: verificar la carga de trabajo de enfermería medida por la Nursing Activities Score en una unidad coronaria, su relación con los turnos de trabajo y comparar el cuadro de enfermería existente en la unidad con lo proyectado según los dados del instrumento. Método: estudio longitudinal realizado en un hospital universitario de la región sur de Brasil en el periodo de abril a junio de 2012. Resultados: se realizaron 604 medidas por turnos, en una muestra de 61 pacientes. La carga de trabajo fue del $47 \%( \pm 12)$ en el análisis por turnos, con promedios más elevados en el turno de la tarde.

Conclusión: se observó la necesidad de en promedio dos y hasta 2,4 profesionales de enfermería, estando consistente con el cuantitativo real de la unidad. El instrumento posibilito medir la carga de trabajo de enfermería e delinear la variabilidad de las demandas en los diferentes turnos de trabajo.

Palabras clave: Enfermería. Cardiología. Cuidados intensivos. Carga de trabajo.
D0l: http://dx.doi.org/10.1590/19831447.2015.03.51367

- Universidade Federal do Rio Grande do Sul (UFRGS). Escola de Enfermagem. Porto Alegre, Rio Grande do Sul, Brasil. | Hospital de Clínicas de Porto Alegre (HCPA). Porto Alegre, Rio Grande do Sul, Brasil.

b Universidade Federal do Rio Grande do Sul (UFRGS) Escola de Enfermagem, Porto Alegre, Rio Grande do Sul, Brasil.

' Hospital de Clínicas de Porto Alegre (HCPA), Porto Alegre, Rio Grande do Sul, Brasil.

${ }^{`}$ Universidade Federal do Rio Grande do Sul (UFRGS). Escola de Enfermagem. Programa de Pós-Graduação em Enfermagem. Porto Alegre, Rio Grande do Sul, Brasil. | Universidade Federal do Rio Grande do Sul (UFRGS). Faculdade de Medicina. Programa de PósGraduação em Cardiologia e Ciências Cardiovasculares. Porto Alegre, Rio Grande do Sul, Brasil. 


\section{口INTRODUCTION}

The advent of modern treatments in specialized and intensive care units has brought significant advances to nursing practice. The new demands in these areas require the constant reevaluation of the size and qualifications of nursing staff to ensure the quality and safety of interventions ${ }^{(1)}$. A growing body of evidence has pointed to an association between the adequacy of the nursing staff and the quality of patient care ${ }^{(2-4)}$.

Therefore, the assessment of nursing workload in distinct units of different types of patients has become a crucial method of assessing these individuals'actual treatment needs. Studies on the topic have become an important source of evidence for decisions regarding staff sizing as well as the division of labor among the nursing team ${ }^{(5)}$.

In light of these developments, instruments to assess patient clinical conditions and care needs have become an indispensable part of cost-benefit analyses in patient care and of evaluations of the quality of care, which could be delivered by different numbers of nurse practitioners(6).

Although several such as instruments are available, the Nursing Activities Score (NAS) $)^{(7)}$ has been described as one of the most reliable methods for the classification of patient clinical status and for the assessment of the workload in intensive care nurses ${ }^{(6,8)}$. This instrument has detected high nursing workloads in general and specialized intensive care units (ICU), with median scores ranging from $66.6 \%$ to $74,4 \%{ }^{(5,9-10)}$. The NAS is also applicable to units with highly care-dependent patients ${ }^{(11)}$, individuals with longer postanesthetic recovery periods ${ }^{(12)}$ and to specialized inpatient units ${ }^{(13-14)}$.

Although the assessment of nursing workload using the NAS could make significant contributions to both the literature and clinical practice, a brief review of the literature revealed that most studies using this instrument focused on general ICUs and, in cardiology studies, only in postoperative heart surgery patients ${ }^{(8,10,15)}$. Very little is known regarding nursing care demands of clinical patients in intensive cardiology care units.

Therefore, the present study aimed to address this gap in the literature by using the NAS to assess nursing workload in a coronary care unit (CCU), assess the distribution of workload between shifts, and compare the actual staff size of the care unit with that recommended by the instrument.

\section{METHODS}

This was a longitudinal study conducted between April and June 2012 in a CCU in a public teaching hospital, which treated predominantly clinical cardiology patients from the metropolitan region of Porto Alegre.

The sample comprised adult patients who stayed in the unit for at least 24 hours. Patients for whom NAS was not available for at least one shift were excluded from the sample.

The sample size was calculated based on the database of a pilot project on the application of the NAS in the same hospital unit between September and November 2011. To detect a five-point difference between shifts (considering a standard deviation of 13 points), with a significance of $5 \%$ and a power of $80 \%$, a convenience sample of 55 patients would be required to provide a total of 108 NAS measures per shift.

A version of the NAS translated and validated for application in a Brazilian population ${ }^{(6)}$ was used to collect patient identification data and information regarding their stay in the CCU. The instrument contains seven categories comprising 23 items, and allows for a calculation of the number of nursing staff required per shift.

The instrument is used by nurses to assign a score to each patient, which corresponds to the percentage of time spent by the nursing team in direct care. The sum of NAS items can reach a maximum value of $176.8 \%{ }^{(7)}$, where a score of $100 \%$ suggests that the activities involved in the care of the patient required $100 \%$ of a nursing professional's time.

The on-call nurses used the NAS to evaluate the level of care required by each patient at the end of every work shift (6-hour shifts in the morning and afternoon, and a 12-hour night shift). When patients were discharged during the shift, the instrument was administered immediately prior to discharge. If another patient was admitted to the same bed prior to the end of the shift, the NAS was applied again. The use of the NAS already was implemented as a routine activity for nurses in the unit as part of an institutional initiative launched in 2012.

The data were entered into a Microsoft Excel ${ }^{\circ}$ 97-2003 spreadsheet, and analyzed using the Statistical Package for the Social Sciences software, version 18.0. Continuous variables were described as mean and standard deviation or median and interquartile ranges, and categorical variables were expressed as absolute numbers and relative frequencies.

The association between work shifts and NAS results was investigated using a generalized estimation equation model and a least significant difference (LSD) test. Pearson and Spearman's correlation coefficients were used to analyze the correlations between mean 24h NAS results and continuous variables such as age and length of hospitaliza- 
tion. Mean NAS results were compared between patients with different reasons for hospitalization using Analyses of Variance (ANOVA) and LSD tests. Results were considered significant at $p<0.05$.

The staff size recommended by the NAS was identified through the sum of the shift (morning, afternoon and night) and 24h patient scores on days in which the unit was fully occupied. On days in which patients were discharged or admitted, resulting in more than four assessments in a single shift, the lowest value was not considered in the sum of the shift and $24 \mathrm{~h}$-scores.

The study was conducted according to national and international human research ethics guidelines. It was approved by the Research Ethics Committee of the institution (CAAE protocol number 00637712.0.0000.5327), which was also sent a research confidentiality form signed by all researchers involved in the project.

\section{RESULTS}

Seventy-nine patients were admitted to the unit during the study period. Nine of these were not included in the study for staying in the unit for less than 24 hours, and another nine were excluded due to missing NAS shift scores. The final sample was composed of 61 patients with a av- erage age of $65( \pm 14)$ years, of whom $37(61 \%)$ were male. The mean length of hospital stay was 2 (2-4) days. The most common reason for hospitalization was acute coronary syndrome (31\%), followed by percutaneous procedures (28\%), arrhythmia (15\%), endovascular aortic aneurysm repair (10\%), and heart failure and other reasons (8\%). The mortality rate in the sample was $1.6 \%$.

A total of 604 shifts (197-morning shift; 208 - afternoon shift; 199 - night shift) and 249 daily NAS scores were obtained. The mean NAS shift score was $47 \%( \pm 12)$, suggesting that patients required, on average, 2.8 hours of direct nursing care in each six hour-shift. The mean NAS results per shift were: morning, 47\% ( \pm 10.9$)$; afternoon, $48 \%( \pm 14)$ and night $46 \%( \pm 11)$. The difference between these values was statistically significant (Figure 1).

The most commonly endorsed items and sub-items in the morning shift were: 3 - Medication (100\%); 7a - Support and care of either relatives or patient requiring full dedication for about 30' and 17 - Quantitative urine output measurement (99.5\%). The following items were most frequently endorsed in the afternoon shift: 17 - Quantitative urine output measurement (100\%), 3 - Medication (99.5\%); $7 a$ - Support and care of either relatives or patient requiring full dedication for about 30' (98.6\%). Lastly, the most commonly mentioned items in the night shift were: 3 - Medica-

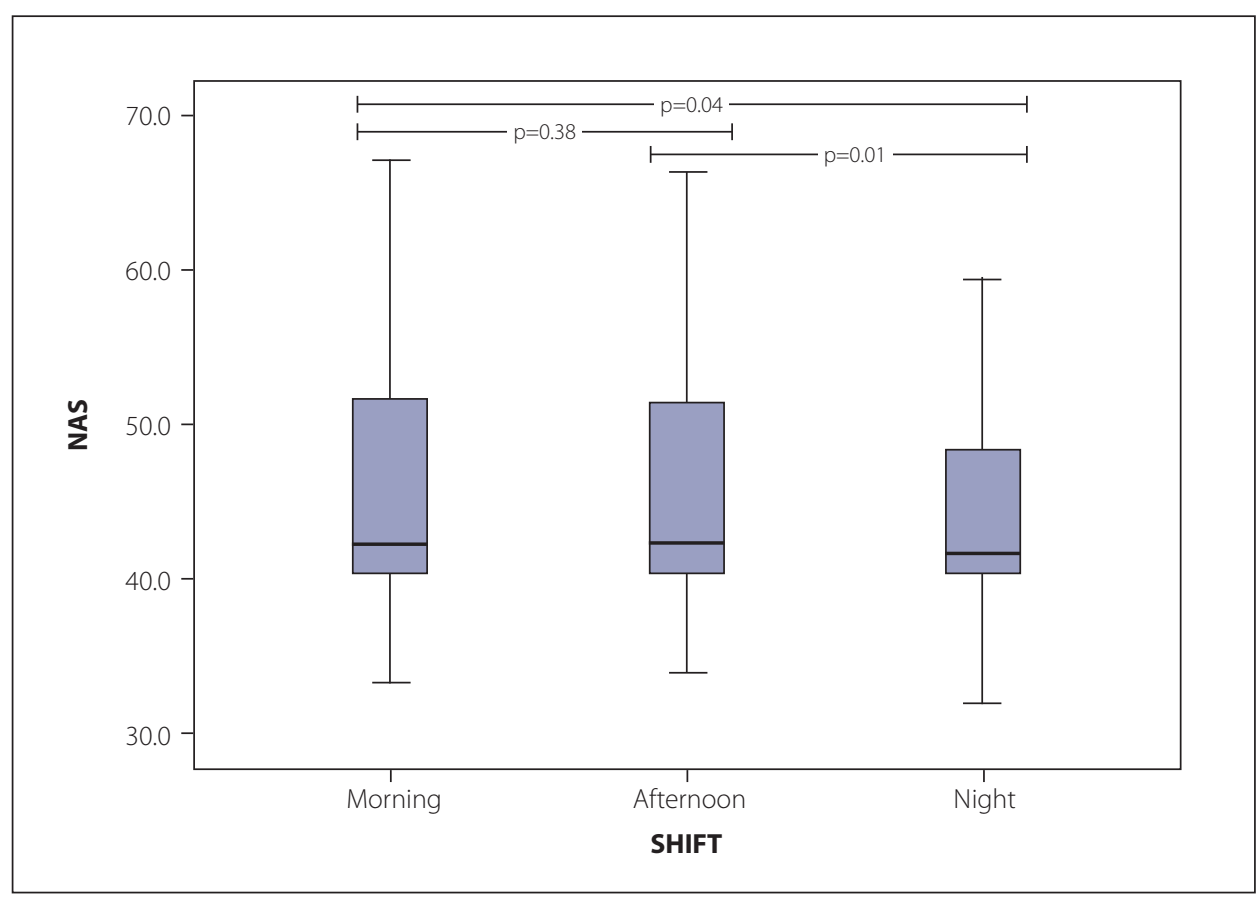

Figure 1 - Between-shift comparisons of Nursing Activities Score. Generalized Estimating Equations and Least Significant Difference tests to calculate $p$ - value Source: Research data, 2012. 
tion (100\%), 17 - Quantitative urine output measurement (99\%) and 8a - Performing routine tasks (98\%). These results are displayed in Chart 1.

The mean 24h NAS for patients admitted at any time of the day was $51 \%( \pm 15)$. Patient age and length of stay in the unit were not significantly correlated. The reasons for hospitalization were significantly associated with nursing workload. Patients admitted for heart failure, and endovascular aneurism repair had higher nursing demands than the remainder of the sample, as indicated by average NAS of $58 \%( \pm 9)$ and $57.7 \%( \pm 7.5)$ respectively. No significant differences were found among the remaining groups of patients.

Workload analyses revealed that the mean NAS results per shift were 183.5 in the morning, 181.9 in the afternoon and 172.9 at night. The mean 24h NAS outcome was 198.3 points. According to these results, the unit would require a staff size of 1.8 nurses per shift, on average, and two nurses per day. Additionally, at different points in each shift and $24 \mathrm{~h}$ period, there was a need for more than two nurses on at least one occasion. Currently, the nursing staff at the CCU studied consists of one nurse and two nurse technicians. These data are displayed in (Chart 2).

\section{DISCUSSION}

The present findings helped to fill the gap in the literature regarding the applicability of the NAS to clinical practice in a CCU. The instrument can assist with the sizing of nursing staff, and with the planning of interventions tailored to patient demands in the different work shifts.

In the present study, the NAS revealed that nurses were required to dedicate $47 \%( \pm 12)$ of their time to direct patient care. This corresponds to 2.8 hours in a 6 -hour shift. A previous study in a cardiology ICU found that nurses spent 5.3 of their 8 hours of work providing direct assistance to patients ${ }^{(10)}$. The increased need for assistance found in the study in question may be attributable to the predominance of postsurgical patients in the sample. In the immediate postoperative period of heart surgery, studies have reported mean NAS scores of $96.79( \pm 3.68)^{(15)}$. In this case, the increased nursing demands may be because these patients require prolonged continuous observation given the high risk of hemodynamic instability, as well as specific post-surgical care (e.g. drains, catheters, monitoring).

The greatest workload was reported in the afternoon, followed by the morning. Workload during both these shifts differed significantly from that reported in the night shift. These findings do not corroborate previous studies in general ICUs, which found that NAS scores were higher in night shifts than during other times of the day ${ }^{(8)}$. This may be due to differences in work dynamics associated with the profile of the patients in the unit. As well as admitting patients with more comorbidities, these ICUs involve activities, which are usually performed at night, such as dressing changes, bed baths, and the collection of biological material for routine analysis. On the other hand, in unit in which most patients were conscious, such as the one in which the present study was conducted, the need to maintain the stability of patients' sleep cycles may require that some activities only be performed during the day.

The analysis of between-shift differences in nursing demands revealed that the most commonly endorsed items in all shifts referred to medication, quantitative urine output measurement, the support of patient and family for about 30', as well as the performance of routine tasks, such as the monitoring of vital signs, the regular registration of fluid balance, the performance of laboratory tests and normal hygiene procedures, as well as the administration of vasoactive medications. Studies conducted in general, and specialized ICUs corroborate our findings regarding the frequency of endorsement of items tapping into medication use, quantitative urine output measurement, laboratory tests and patient/family support in $24 \mathrm{~h}$ NAS scores ${ }^{(8,15)}$. The frequency with which these activities are cited shed light on the daily functioning of ICUs and on the main contributors to nursing workload, as these are frequent and repetitive tasks, which require knowledge and skills beyond the technical.

There were significant differences between shifts in the frequency with which the item "Specific interventions outside the intensive care unit" was endorsed. This item was marked in $47 \%$ of assessments in the afternoon shift, 25\% in morning assessments, and only $7 \%$ of night-time evaluations. This may be associated with the fact that physician rounds in the CCU generally occur in the morning, and it is at this point that treatment plans are made. Examinations and procedures are also requested and performed in the same shift or the following one, often outside the unit. There is also a close relationship between the ICU and the hospital's Hemodynamics Laboratory, where patients are referred for clinical procedures, or hospitalized following examinations or interventions, which require intensive care.

It is important to note that the distinction in NAS between shifts was not large enough to warrant different staff sizes for each shift. However, the changes observed over the course of the day may yet help to plan the staffing of the unit and to distribute the nursing team more adequately, both of which are still challenges in the clinical setting ${ }^{(16)}$. 


\begin{tabular}{|c|c|c|c|c|c|c|}
\hline \multirow[t]{2}{*}{ NAS items and subitems (summarized) } & \multicolumn{2}{|c|}{$\begin{array}{l}\text { Morning } \\
(197)\end{array}$} & \multicolumn{2}{|c|}{$\begin{array}{l}\text { Afternoon } \\
(208)\end{array}$} & \multicolumn{2}{|c|}{ Night (199) } \\
\hline & $\mathbf{f}$ & $\%$ & f & $\%$ & f & $\%$ \\
\hline $\begin{array}{l}\text { 1a. Hourly vital signs, regular registration and calculation of fluid balance } \\
\text { (4.5 pts) }\end{array}$ & 176 & 89.3 & 188 & 90.4 & 175 & 87.9 \\
\hline $\begin{array}{l}\text { 1b. Present at bedside and continuous observation or active for } 2 \text { hrs or } \\
\text { more ( } 12.1 \mathrm{pts})\end{array}$ & 17 & 8.6 & 16 & 7.7 & 19 & 9.5 \\
\hline 1c. Present at bedside and active for 4 hrs or more (19.6 pts) & 4 & 2 & 4 & 1.9 & 5 & 2.5 \\
\hline 2. Laboratory tests: biochemical and microbiological (4.3 pts) & 177 & 89.8 & 179 & 86.1 & 182 & 91.5 \\
\hline 3. Medication, except vasoactive drugs (5.6 pts) & 197 & 100 & 207 & 99.5 & 199 & 100 \\
\hline 4a. Performing hygiene procedures - normal (4.1 pts) & 174 & 88.3 & 181 & 87 & 181 & 91 \\
\hline 4b. Performing hygiene procedures - beyond normal (16.5 pts) & 23 & 11.7 & 26 & 12.5 & 18 & 9 \\
\hline 4c. Performing hygiene procedures - far beyond normal (20.0 pts) & 0 & 0 & 1 & 0.5 & 0 & 0 \\
\hline 5. Care of drains (1.8 pts) & 54 & 27.4 & 60 & 28.8 & 61 & 30.7 \\
\hline 6a. Performing procedure(s) up to three times per 24 hrs (5.5 pts). & 133 & 67.5 & 143 & 68.8 & 150 & 75.4 \\
\hline $\begin{array}{l}\text { 6b. Performing procedure(s) more frequently than three times per } 24 \\
\text { hrs, or with two nurses, with any frequency. (5.5 pts). }\end{array}$ & 42 & 21.3 & 41 & 19.7 & 38 & 19.1 \\
\hline $\begin{array}{l}\text { 6c. Performing procedure with three or more nurses, with any frequency } \\
\text { (17.0 pts). }\end{array}$ & 22 & 11.2 & 24 & 11.5 & 11 & 5.5 \\
\hline $\begin{array}{l}\text { 7a. Support and care of either relatives or patient requiring full } \\
\text { dedication for about } \leq 30^{\prime} / \leq 2 \mathrm{~h} \text { (4.0 pts). }\end{array}$ & 196 & 99.5 & 205 & 98.6 & 194 & 97.5 \\
\hline $\begin{array}{l}\text { 7b. Support and care of either relatives or patient requiring full } \\
\text { dedication for }>30^{\prime} />2 \mathrm{~h} \text { (32.0 pts). }\end{array}$ & 1 & 0.5 & 2 & 1 & 0 & 0 \\
\hline 8a. Performing routine tasks - normal (4.2 pts) & 194 & 98.5 & 203 & 97.6 & 195 & 98 \\
\hline $\begin{array}{l}\text { 8b. Performing administrative and managerial tasks requiring full } \\
\text { dedication for about } 2 \text { hours ( } 23.2 \text { pts). }\end{array}$ & 3 & 1.5 & 4 & 1.9 & 4 & 2 \\
\hline $\begin{array}{l}\text { 8c. Performing administrative and managerial tasks requiring full } \\
\text { dedication for about } 4 \text { hours or more ( } 30.0 \text { pts). }\end{array}$ & 0 & 0 & 1 & 0.5 & 0 & 0 \\
\hline 9. Respiratory support (1.4 pts) & 82 & 41.6 & 80 & 38.5 & 70 & 35.2 \\
\hline 10. Care of artificial airways. orotracheal tube or tracheostomy cannula & 5 & 2.5 & 5 & 2.4 & 3 & 1.5 \\
\hline 11. Treatment for improving lung function (4.4 pts). & 8 & 4.1 & 8 & 3.8 & 7 & 3.5 \\
\hline 12. Vasoactive medication (1.2 pts). & 176 & 89.3 & 178 & 85.6 & 172 & 86.4 \\
\hline 13. Intravenous replacement of large fluid losses ( 2.5 pts). & 3 & 1.5 & 4 & 1.9 & 3 & 1.5 \\
\hline 14. Left atrium monitoring (1.7 pts). & 2 & 1 & 3 & 1.4 & 2 & 1 \\
\hline 15. Cardiopulmonary resuscitation in the previous 24 hrs (7.1 pts). & 0 & 0 & 1 & 0.5 & 0 & 0 \\
\hline 16. Hemofiltration techniques. Dialysis techniques (7.7 pts). & 0 & 0 & 0 & 0 & 0 & 0 \\
\hline 17. Quantitative urine output measurement (7.0 pts). & 196 & 99.5 & 208 & 100 & 197 & 99 \\
\hline 18. Measurement of intracranial pressure (1.6 pts). & 0 & 0 & 0 & 0 & 0 & 0 \\
\hline 19. Treatment of complicated metabolic acidosis/alkalosis (1.3 pts). & 0 & 0 & 0 & 0 & 0 & 0 \\
\hline 20. Intravenous hyperalimentation (2.8 pts). & 0 & 0 & 0 & 0 & 0 & 0 \\
\hline 21. Enteral feeding (1.3 pts). & 12 & 6.1 & 12 & 5.8 & 11 & 5.5 \\
\hline 22. Specific interventions in the intensive care unit (2.8 pts). & 14 & 7.1 & 21 & 10.1 & 16 & 8 \\
\hline 23. Specific interventions outside the intensive care unit (1.9 pts). & 50 & 25.4 & 98 & 47.1 & 14 & 7 \\
\hline
\end{tabular}

Chart 1 - Frequency of Nursing Activities Scores item endorsement per shift Source: Research data, 2012. 


\begin{tabular}{|c|c|c|c|c|c|c|c|c|c|c|c|c|}
\hline \multirow[b]{2}{*}{ Date } & \multicolumn{3}{|c|}{ Morning } & \multicolumn{3}{|c|}{ Afternoon } & \multicolumn{3}{|c|}{ Night } & \multicolumn{3}{|c|}{$24 h$} \\
\hline & $\begin{array}{l}\text { Sum } \\
\text { NAS }\end{array}$ & $\begin{array}{l}\text { Required } \\
\text { staff size } \\
\text { accord- } \\
\text { ing to } \\
\text { NAS }\end{array}$ & $\begin{array}{c}\text { Staff } \\
\text { size } \\
\text { in the } \\
\text { unit }\end{array}$ & $\begin{array}{l}\text { Sum } \\
\text { NAS }\end{array}$ & $\begin{array}{l}\text { Required } \\
\text { staff size } \\
\text { accord- } \\
\text { ing to } \\
\text { NAS }\end{array}$ & $\begin{array}{l}\text { Staff } \\
\text { size } \\
\text { in the } \\
\text { unit }\end{array}$ & $\begin{array}{l}\text { Sum } \\
\text { NAS }\end{array}$ & $\begin{array}{l}\text { Required } \\
\text { staff size } \\
\text { accord- } \\
\text { ing to } \\
\text { NAS }\end{array}$ & $\begin{array}{c}\text { Staff } \\
\text { size } \\
\text { in } \\
\text { the } \\
\text { unit }\end{array}$ & $\begin{array}{l}\text { Sum } \\
\text { NAS }\end{array}$ & $\begin{array}{l}\text { Required } \\
\text { staff size } \\
\text { accord- } \\
\text { ing to } \\
\text { NAS }\end{array}$ & $\begin{array}{c}\text { Mean } \\
\text { staff/ } \\
\text { shift }\end{array}$ \\
\hline 25-Apr & 185.5 & 1.8 & 3.0 & 185.5 & 1.8 & 3.0 & 185.5 & 1.8 & 3.0 & 186.9 & 1.9 & 3.0 \\
\hline 27-Apr & 192.8 & 1.9 & 3.0 & 221.1 & 2.2 & 3.0 & 179.8 & 1.8 & 3.0 & 240.1 & 2.4 & 3.0 \\
\hline 28-Apr & 180.4 & 1.8 & 3.0 & 174.8 & 1.7 & 3.0 & 184.1 & 1.8 & 3.0 & 187.8 & 1.9 & 3.0 \\
\hline 30-Apr & 181.1 & 1.8 & 3.0 & 179.7 & 1.8 & 3.0 & 177.9 & 1.8 & 3.0 & 199.8 & 2.0 & 3.0 \\
\hline 1-May & 172.1 & 1.7 & 3.0 & 155.1 & 1.5 & 3.0 & 158.0 & 1.6 & 3.0 & 174.7 & 1.7 & 3.0 \\
\hline 5-May & 183.0 & 1.8 & 3.0 & 189.2 & 1.9 & 3.0 & 159.9 & 1.6 & 3.0 & 194.2 & 1.9 & 3.0 \\
\hline 6-May & 181.8 & 1.8 & 3.0 & 178.0 & 1.8 & 3.0 & 163.7 & 1.6 & 3.0 & 181.8 & 1.8 & 3.0 \\
\hline 9-May & 208.5 & 2.1 & 3.0 & 193.2 & 1.9 & 3.0 & 165.9 & 1.6 & 3.0 & 219.2 & 2.2 & 3.0 \\
\hline 12-May & 182.9 & 1.8 & 3.0 & 157.4 & 1.6 & 3.0 & 171.7 & 1.7 & 3.0 & 189.8 & 1.9 & 3.0 \\
\hline 13-May & 178.3 & 1.8 & 3.0 & 175.0 & 1.7 & 3.0 & 171.7 & 1.7 & 3.0 & 187.2 & 1.9 & 3.0 \\
\hline 14-May & 169.9 & 1.7 & 3.0 & 173.1 & 1.7 & 3.0 & 208.4 & 2.1 & 3.0 & 213.6 & 2.1 & 3.0 \\
\hline 9-Jun & 185.9 & 1.8 & 3.0 & 201.3 & 2.0 & 3.0 & 149.0 & 1.5 & 3.0 & 205.0 & 2.0 & 3.0 \\
\hline $\begin{array}{l}\text { Mean } \\
\text { over } \\
\text { time }\end{array}$ & 183.5 & 1.8 & 3.0 & 181.9 & 1.8 & 3.0 & 172.9 & 1.7 & 3.0 & 198.3 & 2.0 & 3.0 \\
\hline
\end{tabular}

Chart 2 - Sum of Nursing Activities Scores and required staff size according to the instrument, and actual number of in the unit per shift and per day

Source: Research data, 2012.

According to the $24 \mathrm{~h}$ NAS, $51 \%( \pm 15)$ of nurses' time were consumed in the CCU. This result is similar to that obtained in highly nursing-dependent patients and nephrology units, which offer both clinical and surgical treatments. In such locations, Brazilian studies have found NAS of 50\% or higher ${ }^{(11,13)}$. These findings suggest that patients in specialized units demand a high proportion of nurses' time due to the need for specific care and monitoring procedures, which require that nurses spend over half their shifts performing direct care duties.

No significant correlations were found between the workload demanded by each patient, their age, and length of stay in the unit. Similar results regarding patient age have been obtained by other study ${ }^{(10)}$. An analysis of the workload demanded by patients with acute coronary syndrome, acute respiratory insufficiency and sepsis in an ICU revealed lower workloads in patients with coronary syndrome until the seventh day of hospitalization, after which workload scores became similar for all three groups ${ }^{(17)}$. Therefore, the fact that patients in the present sample only stayed in the unit for short periods may have influenced our results.
A significant association was found between workload and the reasons for hospitalization, with individuals hospitalized for heart failure and endovascular aneurysm repair presenting greater nursing demands. A study in a general ICU revealed that the complexity and intensity of patient care are associated with the impact on nursing workload ${ }^{(18)}$. A study conducted in a gastroenterology unit revealed a significant difference between the workloads of clinical and surgical nurses ${ }^{(14)}$. It is also evident in clinical practice that patients with certain conditions rely more on nurses and, consequently, demand greater workloads.

The assessment of associations between patient status, dependence on nurses and workload would allow for the more efficient planning of daily activities in the unit by shedding light on patient needs and ways to avoid an excessive workload.

When CCU workload was converted to the length of time demanded by each patient, we found that coronary patients require, on average, 12.2 hours of direct nursing care during every $24 \mathrm{~h}$-period. This is a longer period than that recommended by COFEN Resolution Number 293/04 
for ICU patients considered to require semi-intensive care, which are expected to demand 9.4 hours of nursing time during every $24 \mathrm{~h}$ shift ${ }^{(19)}$. However, it is a shorter period than that expected to be demanded by patients requiring intensive care, which is of 17.9 hours. The duration of assistance found in the present study is similar to that described by studies of cardiopathic patients, who are potentially subject to hemodynamic stability and changes in clinical status. When these changes occur, patients often require vasoactive drugs, continuous bedside observation, and more assistance than that provided to semi-intensive care patients.

The NAS suggested that a mean number of 1.8 nurses per shift and two nurses per day would be required to perform all required tasks in the CCU. The difference between these values may be attributed to the weighing of items in the NAS, which assigns higher values to activities, which occur with a high frequency or prolonged duration over the course of 24h, but not during each individual shift.

The staff size suggested by the NAS was lower than the number of nurses who actually worked in the unit, which employs a three-person nursing team for both the day and night shifts, comprising one nurse and two nurse technicians. However, it is important to note that in both individual shifts and $24 \mathrm{~h}$ periods, on at least one of the days on which data was collected, more than 2 workers were required on at least one occasion. This was corroborated by NAS item scores, which revealed that the item "Performing the procedure with three or more nurses, with any frequency," was endorsed by nurses in several shifts over the course of the study period. Therefore, the NAS suggested that up to 2.4 nursing professionals would be required to attend to the demands of the four-bed CCU in which this study was conducted.

According to the NAS, the number of nursing professionals currently employed in the unit is adequate for its demands. An adequately sized staff is crucial to ensure the quality of care and decrease the frequency of adverse events in critically ill patients. Understaffing is related to increased infection and mortality rates, an increased frequency of falls, pneumonia associated with mechanical ventilation, accidental extubation and length of stay in the ICU ${ }^{(20)}$.

The applicability of the NAS for the assessment of workload during shifts and $24 \mathrm{~h}$ periods is an important facilitator for the management of ICUs, since it allows for the efficient distribution of the staff throughout the unit, in nursing teams, and for the achievement of an optimal staff per patient ratio.

The present findings showed that the NAS is also applicable to coronary units, in which it can adequately assess nursing workload and describe the nursing demands in different work shifts.

\section{- CONCLUSION}

The mean nursing workload in CCU studied, according to the NAS, was of $51 \%$. The conversion of this value to time spent in direct care revealed that each patient required approximately 12.2 hours of direct nursing care during every 24-hour period.

Comparisons of nursing workload between shifts showed that the highest nursing demands took place in the afternoon shifts, which had a mean NAS of $48.0 \%$.

The amount of time required by each patient was not correlated with age or length of stay in the unit, although it did show an association with the reason for hospitalization.

According to the instrument, a mean of 2 and a maximum of 2.4 nurses would be necessary to attend to the demands of the four-bed CCU. The current staff size of the unit, which employs three nurses per shift, is in accordance with these specifications.

\section{口EFERENCES}

1. Inoue KC, Matsuda LM. Dimensionamento de pessoal de enfermagem em unidade de terapia intensiva para adultos. Acta Paul Enferm. 2010;23(3):379-84.

2. Cho SH, Kim YS, Yeon KN, You SJ, Lee ID. Effects of increasing nurse staffing on missed nursing care. Int Nurs Rev. 2015;62(1):1-8.

3. Cho E, Sloane DM, Kim EY, Kim S, Choi M, Yoo IY, et al. Effects of nurse staffing, work environments, and education on patient mortality: an observational study. Int J Nurs Stud. 2015:52(2):535-42.

4. Zhu X, You L, Zheng J, Liu K, Fang J, Hou S, et al. Nurse staffing levels make a difference on patient outcomes: a multisite study in Chinese hospitals. J Nurs Scholarsh. 2012;44(3):266-73.

5. Altafin JAM, Grion CMC, Tanita MT, Festti J, Cardoso LTQ, Veiga CF, et al. Nursing Activities Score e carga de trabalho em unidade de terapia intensiva de hospital universitário. Rev Bras Ter Intensiva. 2014;26(3):292-8.

6. Queijo AF, Padilha KG. Nursing Activities Score (NAS): adaptação transcultural e validação para a língua portuguesa. Rev Esc Enferm USP. 2009;43(nesp):1018-25.

7. Miranda DR, Nap R, Rijk A, Schaufeli W, lapichino G. Members of the TISS Working Group. Nursing activities score. Crit Care Med. 2003;31(2):374-82.

8. Conishi RMY, Gaidzinski RR. Nursing Activities Score (NAS) como instrumento para medir carga de trabalho de enfermagem em UTI adulto. Rev Esc Enferm USP. 2007;41(3):346-54.

9. Goulart LL, Aoki RN, Vegian CFL, Guirardello EB. Carga de trabalho de enfermagem em uma unidade de terapia intensiva de trauma. Rev. Eletr. Enf [Internet]. 2014 [citado 2014 mar. 20];16(2): 346-51.

10. Coelho FUA, Queijo AF, Andolhe R, Gonçalves LA, Padilha KG. Carga de trabalho de enfermagem em unidade de terapia intensiva de cardiologia e fatores clínicos associados. Texto Contexto Enferm. 2011;20(4):735-41. 
11. Lima MKF, Tsukamoto R, Fugulin FMT. Aplicação do nursing activities score em pacientes de alta dependência de enfermagem. Texto Contexto Enferm. 2008;17(4):638-46.

12. Lima LB, Rabelo ER. Carga de trabalho de enfermagem em unidade de recuperação pós-anestésica. Acta Paul Enferm. 2013;26(2):116-22.

13. Trepichio PB, Guirardello EB, Duran ECM, Brito AP. Perfil dos pacientes e carga de trabaIho de enfermagem na unidade de nefrologia. Rev Gaúcha Enferm. 2013;34(2):133-9.

14. Panunto MR; Guirardello EB. Nursing workload at a gastroenterology unit. Rev Latino-Am. Enfermagem. 2009;17(6):1009-14.

15. Dias MCCB. Aplicação do Nursing Activities Score - N.A.S. como instrumento de medida de carga de trabalho de enfermagem em UTI Cirúrgica Cardiológica [dissertação]. São Paulo: Universidade de São Paulo, Escola de Enfermagem; 2006 [citado 2014 mar. 20]. Disponível em: http://www.teses.usp.br/teses/ disponiveis/7/7131/tde-17102006-131800/pt-br.php

16. Girardello DTF, Nicola AL, Fernandes LM. Assistência de enfermagem: horas requeridas para o cuidado do paciente crítico. Rev Rene. 2013;14(6):1084-91.

\section{Author's address:}

Eneida Rejane Rabelo-Silva

Escola de Enfermagem

Universidade Federal do Rio Grande do Sul

Rua São Manoel, 963, Rio Branco

90620-110 Porto Alegre-RS

E-mail: eneidarabelo@gmail.com
17. Carmona-Monge FJ, Jara-Pérez A, Quirós-Herranz C, Rollán-Rodríguez G, CerriIlo-González I, García-Gómez S, et al. Assessment of nursing workload in three groups of patients in a spanish ICU using the Nursing Activities Score scale. Rev Esc Enferm USP. 2013;47(2):331-6.

18. Lucchini A, Elli S, Bambi S, Foti G, Fumagalli R. Ventilazione invasiva e non invasiva: impatto sul carico di lavoro infermieristico. Assist Inferm Ric. 2013;32(3):124-31.

19. Conselho Federal Enfermagem (BR). Resolução № 293/2004. Fixa e estabelece parâmetros para dimensionamento do quadro de profissionais de enfermagem nas unidades assistenciais das instituiç̧ões de saúde e assemelhados [Internet]. 2004 [citado 2014 mar. 20]. Disponível em: http://novo.portalcofen.gov.br/ resoluo-cofen-2932004_4329.html

20. Versa GLGS, Inoue KC, Nicola AL, Matsuda LM. Influência do dimensionamento da equipe de enfermagem na qualidade do cuidado ao paciente crítico. Texto Contexto Enferm. 2011;20(4):796-802.
Received: 06.11.2014

Approved: 24.06.2015 